DOI: $10.21802 / \mathrm{artm} .2020 .3 .15 .216$.

UDC $340.6+343$

\title{
STUDY OF ETHNIC AND REGIONAL FEATURES OF DERMATOGLYPHIC PARAMETERS OF HANDS AND FEET (LITERATURE REVIEW)
}

\author{
I.V. Gunas ${ }^{1}$, O.V. Dunayev ${ }^{2}$, O.G. Popadynets ${ }^{3}$, R.V. Kozoviy ${ }^{4}$, E.O.Kindrativ ${ }^{5}$ \\ ${ }^{1}$ National Pirogov Memorial Medical University, Vinnytsia, Ukraine, \\ ORCID ID:0000-0003-4260-2301,e-mail: igor.v.gunas@gmail.com; \\ ${ }^{2}$ Kharkiv National Medical University, Department Forensic Medicine and Medical Law, Kharkiv, Ukraine, \\ ORCID ID: 0000-0002-3231-7171,e-mail:sme_khnmu@email.ua; \\ ${ }^{3}$ Ivano-Frankivsk National Medical University, Department of Human Anatomy, Ivano-Frankivsk, Ukraine, \\ ORCID ID: 0000-0002-2093-5984,e-mail: Oksana-g@live.ru; \\ ${ }^{4}$ Ivano-Frankivsk National Medical University, Department of Medical Biology and Medical Genetics, \\ Ivano-Frankivsk,Ukraine,e-mail: ruslan_kozoviy@ukr.net; \\ ${ }^{5}$ Ivano-Frankivsk National Medical University, Department of Pathological Anatomy, \\ Ivano-Frankivsk, Ukraine, ORCID ID: 0000-0002-3894-8484, e-mail: kindrativ2016@gmail.com
}

\begin{abstract}
The article outlines the prospects for studying the ethnic and regional features of dermatoglyphic parameters of hands and feet, given the intensification of migration processes both within Ukraine and worldwide, which each year causes a catastrophic increase in the number of people living outside the country or region origin. Refugees, labor and political migrants, migrants due to racial discrimination and other reasons today make up 3\% of the world's population. The growing flow of world migration and assimilation creates all the conditions for the disappearance of pure ethnic groups and peoples. Therefore, modern scientists are interested in the availability of anthropometric, anthroposcopic, dermatoglyphic data of different populations to create regional gene pools. In the context of the above issues, the issue related to the study of anthroposcopic, anthropometric, dermatoglyphic parameters of the population of Ukraine, taking into account regional and ethno-territorial affiliation, remains relevant. The article also identifies the advantages of using the dermatoglyphic method, which include ease of use, financial burden and the ability to obtain results in a short time. A thorough analysis of the literature on this issue, based on which the main directions of application of dermatoglyphics. It has been determined that dermatoglyphic has been the subject of research by specialists in various fields of knowledge form overe the century. Based on the results of studying the features of dermatoglyphic, anthropometric and anthroposcopic parameters, scientists have proposed a zoning scheme of the territory of Ukraine. The results obtained by studying the comb pattern of human hands and feet still remain an informative source in medicine, criminology, anthropology and population genetics. Genetic conditionality of dermatoglyphic parameters allows to use dermatoglyphics to solve a number of issues that arise during ethno anthropological and populationgenetic studies. Dermatoglyphics is widely used in medicine: clinical (in predicting the likelihood of various pathological conditions) sports (in determining the physical capabilities of the person). In the practice of forensic medicine, dermatoglyphics has until recently been used in the examination of disputed paternity, but in recent decades it has also been actively used in determining family affiliation, analysis of family ties with subsequent use of data to identify unknown persons parameters of relatives. A number of Ukrainian scientists who studied the ethnic features of dermatoglyphic, anthropometric and anthroposcopic parameters, their contribution to Ukrainian ethnodermatoglyphics and outlined prospects for study were identified in the literature analysis. The main key issues considered by scientists from other countries of the world are also identified, the method of studying the ethnic and territorial features of dermatoglyphic, anthropometric and anthroposcopic parameters used by them is evaluated and the results obtained by them are analyzed. In the context of the above, it should be noted that the study of ethnological, regional features of dermatoglyphic parameters of the hands and feet is relevant among the world scientific community. However, currently there are too few works by domestic authors devoted to the study of regional and ethno-territorial features of dermatoglyphic parameters, although given the intensification of migration processes, the prospects for its study are outlined.
\end{abstract}

Keywords: dermatoglyphics, ethnodermatoglyphics, dermatoglyphic parameters.

Introduction. Intensification of migration processes both within Ukraine and within the world, which is the reason for the catastrophic increase in the number of people living outside the country or region of origin. Refugees, labor and political migrants, migrants due to racial discrimination and other reasons today make up 3\% of the world's population [1]. The growing flow of world migration and assimilation creates all the conditions for the disappearance of pure ethnic groups and peoples.
Therefore, modern scientists are interested in the availability of anthropometric, anthroposcopic, dermatoglyphic data of different populations to create regional gene pools. In the context of the above issues, the issue related to the study of anthroposcopic, anthropometric, dermatoglyphic parameters of the population of Ukraine, taking into account regional and ethno-territorial affiliation, remains relevant. 
Dermatoglyphics has been the subject of research by specialists in various fields of knowledge for over a century. The results obtained by studying the comb pattern of human hands and feet still remain an informative source in medicine, criminology, anthropology and population genetics. Genetic conditionality of dermatoglyphic parameters allows to use dermatoglyphics to solve a number of issues that arise during ethno anthropological and population-genetic studies $[2,3,4,5]$. Dermatoglyphics is widely used in medicine: clinical (in predicting the likelihood of various pathological conditions) $[6,7,8]$ sports (in determining the physical capabilities of the person) $[9,10,11]$. In the practice of forensic medicine, dermatoglyphics has until recently been used in the examination of disputed paternity [12], but in recent decades it has also been actively used in determining family affiliation (examination of kinship), analysis of family ties with subsequent use of data to identify unknown persons parameters of relatives [13, 14].

Speaking of Ukrainian ethnodermatoglyphics, it is impossible not to mention the fundamental research of Segeda S.P. [15], who studied the distribution of dermatoglyphic parameters among the population of Ukraine, taking into account their regional and ethno-territorial affiliation, based on the results, analyzed the variations of the leading features of this system and identified local dermatoglyphic variants (complexes) in Ukraine (northern, central and southern).

The northern complex, which covers the majority of the populations of Polissya and Volyn, is characterized by a low and moderate delta index (11.83 - 12.56), increased frequencies of additional interdigital triradius (usually above 20\%) and triradius t (up to 69\%). This peculiar combination of features has analogues among the Belarusians of Central Belarus and the Russians of the North-West and North of the European part of the Russian Federation, which indicates the presence of a northern European morphological component in the outlined regions of Ukraine.

The central complex, distributed in some areas of the Middle Dnieper region, in the South of Volyn and in Galicia, is characterized by the most "western" combination of dermatoglyphic features, namely: medium D110 (12.72 - 13.12), medium-high Cummins index (8.40 $8,63)$, low and moderate percentages of triradius t (53.0 $58.6 \%$ ), high frequency of patterns on the hypotenuse (34.6 -38.7\%) and medium - interdigital additional triradius $(16.1-19.1 \%)$. The close combination of features is characteristic of the Moldavians of Northern Bukovina and the Russians of the South of the European part of the Russian Federation.

The southern complex, distributed on the Right Bank of the Middle Dnieper region, in the steppe zone and in the Carpathians, is characterized by high in Ukraine D110 (12.90 - 13.50), average Cummins index $(8.27-8.58)$, medium-high percentage of triradius $t(62.2$ - $65.3 \%$ ), slightly underestimated number of samples on the hypotenuse $(26.3-30.4 \%)$ and interdigital additional triradius $(10.1$ - 23.6\%). Parallels between the Dnieper and Carpathian populations, identified on the basis of dermatoglyphic data, are associated with the influence of the southern European component. This explains the analogies with the Bulgarians, Gagauz, Moldavians and some groups of Russians in the south of the European part of Russia.

Also S.P. Segeda gave a general dermatoglyphic description of Ukrainians against the background of some other ethnic groups in Eurasia. In particular, it is shown that for most of the leading dermatoglyphic characteristics (except for the Cummins index) Ukrainians in comparison with the total sample of Eastern Europe and Scandinavia deviate in the direction of the Caucasus, where anthropological variants of southern origin are common. Probably, these deviations are due to the influence of the southern European component found in the Middle Dnieper region, in the Carpathians, in the south of Ukraine.

Among the scientists studying the Ukrainian ethnodermatoglyphics it is necessary to note V.I. Gunas The author studied the regional features of finger and palm dermatoglyphics and their relationship with the personality characteristics of almost healthy men in Ukraine. As a result of the author got dermatoglyphic population picture of practically healthy men of Ukraine is covered, administrative-territorial regions with both high phenotypological heterogeneity and high homogeneity of finger dermatoglyphics features are revealed, high phenotypological inhomogeneity of qualitative and quantitative indicators of palmar dermatoglyphs is determined [1].

Nowadays, the study of dermatoglyphic and anthropological features of different ethnic groups and peoples of the world is becoming increasingly popular. As for the dermatoglyphics of other peoples of the world, it should be noted that it has been studied or is studied in various aspects: as a diagnostic and prognostic marker system in medicine, identification marker system in criminology, anthropological marker system of historical, evolutionary processes and genetic structure among populations [16-20].

One of the scientists who used the dermatoglyphic method in anthropological research is G.L. Khit [21], who studied the dermatoglyphic parameters of the peoples of the Caucasus and Transcaucasia. Namely, in her work 1974-75 ("Dermatoglyphics of the peoples of Central Asia in connection with the problems of their origin") [28] highlights the rasogenetic, ethnopopulation relations of the population of the Caucasus, Central Asia and the South European part of the Union of Soviet Socialist Republics.

A great contribution in this direction was made by A.G. Sidorenko [22]. He conducted a comprehensive study of dermatoglyphics of the palms, which allowed him to identify racial and gender differences depending on quantitative and qualitative indicators, taking into account the topography of triradius and volar pattern, as well as the presence or absence of main and additional triradius; found a significant correlation in the manifestation of rare dermatoglyphic features between the palms of children and true parents.

A group of researchers from India [23] studied the patterns of distribution of dermatoglyphic parameters of the distal phalanges of the fingers among the Marathi 
ethnic group in Nagpur. It was found that the most common element was the arc, which was found in $51.3 \%$. In the study of differences in skin pattern between men and women, no statistically significant data were found.

S. Biswas [24] studied the features of the palmar skin pattern in the Dhimala ethnic group living in North Bengal. As a result of statistical analysis of the data found that the most common type of pattern in this ethnic group are curls (found in 52.65\%) and loops (45.25\%). The pattern frequency index was 15.05 , TFRC - 162.18 . The fourth interdigital space contains more patterns $88.73 \%$, and the average value of the angle atd was 42,290 .

Another group of Indian researchers [25] compared the skin patterns of the inhabitants of Western Rajasthan and the Garhwal region of Uttarakhad (100 representatives from each region were taken for the study). The main studied indicators were selected for the study TFRC, absolute comb finger count (AFRC) and angle atd. Statistical processing revealed a significant difference in the studied indicators.

A group of scientists [26] also studied dermatoglyphic features among women of Jin nationality in Guangxi Province. The data obtained were compared with the already known data of the other 5 nationalities living in this province of China. The largest difference was found for the indicators of the palmar $a-b$ comb count, the position of the triradius and the frequency of skin patterns in the area of the tenor I and II interdigital space of the left hand.

The dermatoglyphic method has become widely popular among Chinese scientists who have studied the anthropological and dermatological composition of different ethnicities living in China. Thus, a group of researchers studied the features of the skin pattern in the Han nationality from Guangdong Province [27]. 307 physically healthy students aged 18 to 21 were selected for the study - 157 men and 150 women. The following results were obtained - b-c comb score $(25.86 \pm 5.21)$, a, b comb score $(36.19 \pm$ $5.58)$, a, d comb score $(75.43 \pm 13.11)$, c, d comb score $(32.83 \pm 5.57)$ and $t-d$ comb score $(90.66 \pm 13.50)$. According to the study, most of the values were higher in men. Significant differences in dermatoglyphic parameters were revealed in comparison with the population of Tibet and other regions of China.

Researchers from Argentina conducted a study in which it was decided to find a link between the features of the dermatoglyphic pattern and certain names of people living in the province of Jujuy. The surnames were divided into the following groups - domestic and foreign (depending on this, groups of combinations were formed: when both parents had domestic surnames, only one of them, etc.), mountain and plain. Statistical data processing revealed more frequent patterns such as ulnar and radial loops among people with native names living in the mountains, while curls and arches are more common for people with plain names [28].

D. E. O. Eboh [29] decided to compare the dermatoglyphic drawings of the inhabitants of the ethnic groups Anioma and Urgobo. The study included 820 people, aged 13 to 48, belonging to the Anioma ethnic group (340 people, including 176 men and 164 women) and Urgobo (480 people, including 224 men and 256 women).
The study did not reveal any gender differences in dermatoglyphic parameters, however, it revealed significant associations between skin pattern and ethnicity.

Issues of ethnodermatoglyphics, also actively studied N.A. Suvorova [30] when comparing ethnographic and anthropological data showed that according to anthropological research the contribution of local (genetic) substrate in the formation of physical features of Bashkirs (appearance, morphology of the dental system, dermatoglyphic parameters) looks more significant than historical and ethnographic data. Moreover, if according to craniological research the carriers of this component are mainly women, then according to dermatoglyphics it is no less clearly traced in men.

Peculiarities of dermatoglyphic indicators for residents of different regions of Bulgaria have been studied. The survey of 102 men and 95 women living in the Lyubimets region and 91 men and 105 women living in the Svilehrad region revealed almost no significant differences, which means that the population of these regions is quite homogeneous [31].

In 2016, M. Gautam and U. P. Singh conducted a comparative study of dermatoglyphic parameters among residents of the Khatiks and Kumbhari ethnic groups in Luchnov province. 100 representatives were selected from each of the ethnic groups (50 men and women), who underwent a dermatoglyphic study. For members of the Khatixi group, the largest number of curls, the smallest number of loops and the smallest number of arcs were found. Higher values of most indicators were found for men of both ethnic groups. The affinity of the Khatiks to the ethnic groups of the Boks, Oraons and Bhils in terms of dermatoglyphic indicators has been revealed [32].

Conclusion. In the context of the above, it should be noted that the study of ethnological, regional features of dermatoglyphic parameters of the hands and feet is relevant among the world scientific community. However, currently there are too few works by domestic authors devoted to the study of regional and ethno-territorial features of dermatoglyphic parameters, although given the intensification of migration processes, the prospects for its study are outlined.

\section{Referenses:}

1. Hunas VI. Rehionalni osoblyvosti paltsevoyi i dolonnoyi dermatohlifiky ta yikh zv'yazok iz pokaznykamy osoblyvostey osobystosti praktychno zdorovykh cholovikiv Ukrayiny [dysertatsiya] (in Ukrainian).

2. Kozan NM. Etno-rasovi osoblyvosti dermatohlifichnykh parametriv pal'tsiv nih (povidoml. 1). Sudovo.-medychna ekspertyza. 2013; 2:18-21. (in Ukrainian).

3. Chistikina TA, Zoroastrov OM, Kolomis VE. Osobennosti paltsevoy dermatoglifiki naseleniya Tyumenskoy oblasti. Sudebno-meditsinskaya yekspertiza. 2009; 52(5):11-14. (in Russian).

4. Khit GL, Dolinova NA. Rasovaya differentsiatsiya chelovechestva Dermatoglificheskiye dannyye. M.: Nauka. 1990. P.206. (in Russian).

5. Mishalov V, Serebrennikova A, Hunas V. Dyskryminantni modeli prynalezhnosti praktychno zdorovykh cholovikiv do tsentral'noho,zakhidnoho 
abo skhidnoho administratyvno-terytorialnykh rehioniv Ukrayiny na osnovi polkznykiv paltsevoyi ta dolonnoyi dermatohlifiky. Biomedical and biosocial anthropology. 2017; 29:36-40. (in Ukrainian).

6. Bala A, Deswal A, Sarmah PC, Khandalwal B, Kumar BT. Palmar dermatoglyphics patterns in diabetes mellitus and diabetic with hypertension patients in Gangtok. International Journal of Advanced Research. 2015; 3(4):1117-1125.

7. Babu S, Powar B, Khare O. Palmer Dermatoglyphics in Pulmonary Tuberculosis. Journal of Anatomical Society of India. 2005; 54(2):64-66.

8. Kulic JV, Milicic J, Letinic D. Dermatoglyphics in Patients with Hypothyreosis Coll Antropol. 2012; Jun, 36(2):389-94.

9. Abramova TF Paltsevaya dermatoglifika i fizicheskiye sposobnosti [dissertatsiya]; Moskva. 2003. P.51. (in Russian).

10. Serhiyenko L, Chekmarova N. Dermatohlifichni markery $\mathrm{v}$ henetychnomu prohnozi fenotypichnoho proyavu psykhomotornykh zdibnostey lyudyny. Teoriya ta metodyka fizychnoho vykhovannya. 2008; 5:11-17. (in Ukrainian).

11. Serhiyenko L, Lyshevska V. Dermatohlifika stupni v prohnozi sportyvnoyi obdarovanosti: populyatsiyni osoblyvosti formuvannya dermatohlifiky stupni molodi Ukrayiny (povidomlennya 1). Pedahohika, psykholohiya ta medyko-biolohichni problemy fizychnoho vykhovannya ta sportu. 2013; 1:79-83. (in Ukrainian).

12.Zvyagin V. Dermatoglifika v sudebnoy meditsine. Papillyarnyye uzory: identifikatsiya i opredeleniye kharakteristik lichnosti (daktiloskopiya i dermatoglifika). M. 2002. (in Russian).

13. Bozhchenko AP, Tolmachev IA. Novyy algoritm ustanovleniya krovnogo rodstva na osnove dermatoglificheskogo metoda. Sudebno-meditsinskaya yekspertiza. 2011; 6:19-22. (in Russian).

14. Bozhchenko A, Tolmachev I. Novyy algoritm ustanovleniya krovnogo rodstva na osnove dermatoglificheskogo metoda. Sudebno-meditsinskaya yekspertiza. 2011; 6:19-22. (in Russian).

15. Segeda S.P. Antropolohichnyy sklad ukrayins'koho narodu: etnohenetychnyy aspekt [avtoreferat]. Kyyiv. 2002. P.28. (in Ukrainian).

16. Gutiérrez-Redomero E, Rivaldería N, AlonsoRodríguez C, Martín LM, Dipierri, JE, et al. Are there population differences in minutiae frequencies? A comparative study of two Argentinian population samples and one Spanish sample. Forensic science international, 2012; 222(1-3):266-276.

17. Hussein IA, Abdullah NF. Fingerprint Angles and Patterns in the Population of Najaf Province. Ibn ALHaitham Journal For Pure and Applied Science. 2017; 19(4):21-33.

18. Kahleel SH. Palm-print patterns in population of Diwaniyah City. Al-Qadisiyah Journal Of Pure Science. 2017; 17(2):25-32.

19. Minkov T, Boichev M, Todorov V, Paraskova N, Georgiev V, et all. Dermatoglyphic characterization of bulgarian population from some regions of southeast- ern Bulgaria. Journal Scientific \& Applied Research. 2015; 8:47-53.

20. Otobo TM, Tarimobo-Otobo R. Digital and palmer dermatoglyphic characteristics of the ijaw ethnic group. International Journal of Forensic Medical Investigation. 2016; 2(1):25-30.

21. Khit GL. Dermatoglifika chelovecheskikh ras i populyatsiy: taksonomicheskiy aspekt. Na putyakh biologicheskoy istorii chelovechestva. M. 2002. T.1. (in Russian).

22. Sidorenko A.G. Vozmozhnosti ladonnoy dermatoglifiki pri sudebno-meditsinskoy identifikatsii lichnosti(avtoreferat). Moskva;2006. P.2.

23. Bansal HD, Badiye AD, Kapoor NS. Distribution of Fingerprint Patterns in an Indian Population. Malaysian Journal of Forensic Sciences. 2014. 5(2):18-21.

24. Biswas S. Finger and palmar dermatoglyphic study among the Dhimals of North Bengal, India. Anthropologist 2011; 13(3):235-238.

25. Bokariya P, Kothari R, Waghmare JE, Tarnekar AM, Pal AK,Ingole IV. Comparision of dermatoglyphic pattern of population of western Rajasthan and Garhwal Region of Uttarakhand. Indian Journal of Forensic Medicine \& Toxicology. 2011; 5(2):80-82.

26. Bokariya P, Singhvi SM, Chowdhary DS, Kothari R. Dermatoglyphics pattern of Jain population of Western Rajasthan. Journal of Forensic Medicine and Toxicology. 2010; 27(2):48-50.

27. Chen XY, Yu ZJ, Chen XH. An Analysis of Dermatoglyphics Density of the Han Nationality from Guangdong. Acta Anthropologica Sinica. 2010; 2:159-162.

28. Dipierri JE, Gutiérrez-Redomero E, Alonso-Rodríguez C, Alfaro E, Demarchi, D, et all. Surnames, geographic altitude, and digital dermatoglyphics in a male population from the province of Jujuy (Argentina). HOMOJournal of Comparative Human Biology.2014; 65(3):256-266.

29. Eboh DEO. Digital dermatoglyphic patterns of Amioma and Urhobo students in two tertiary institutions of Delta state, southern. Nigeria. Journal of Medicine and Biomedical Research. 2012; 11(2):90-96.

30. Suvorova NA. Problema formirovaniya antropologicheskogo sostava bashkir po dannym dermatoglifiki i odontologi [dissertatsiya]. Moskva; 2005. P.320. (in Russian).

31. Minkov T, Boichev M, Todorov V, Paraskova N, Georgiev V, et all. Dermatoglyphic characterization of bulgarian population from some regions of southeastern Bulgaria. Journal Scientific \& Applied Research. 2015; 8:47-53.

32. Gautam M, Singh UP. Finger Dermatoglyphics of the Khatiks and Kumbhars of Lucknow, Uttar Pradesh. Voice of Intellectual Man-An International Journal. 2016; 6(1):107-120. 
УДК $340.6+343$

\section{ВИВЧЕННЯ ЕТНІЧНИХ І РЕГІОНАЛЬНИХ ОСОБЛИВОСТЕЙ ДЕРМАТОГЛІФІЧНИХ ПАРАМЕТРІВ РУК І НIГ (ОГЛЯД ЛІТЕРАТУРИ)}

I.В. Гунас ${ }^{1}$, О.В. Дунаєв ${ }^{2}$, О.Г. Попадинець ${ }^{3}$, Р.В. Козовій ${ }^{4}$, Е.О. Кіндратів

${ }^{1}$ Вінницький національний медичний університет імені M.I. Пирогова, кафедра анатомії людини,

м. Вінниия, Україна,

ORCID ID: 0000-0003-4260-2301;

e-mail:igor.v.gunas@gmail.com,

${ }^{2}$ Харківський національний медичний університет, кафедра судової медицини та медичного права,

м. Харків, Україна,

ORCID ID: 0000-0002-3231-7171,

e-mail:smekhnmu@email.ua;

${ }^{3}$ Івано-Франківський національний медичний університет, кафедра анатомії людини,

м. Івано-Франківськ, Украӥна,

ORCID ID: 0000-0002-2093-5984,

e-mail: Oksana-g@live.ru;

${ }^{4}$ Івано-Франківський національний медичний університет, кафедра медичної біологї̈ та медичної генетики,

м. Івано-Франківськ, Украӥна,

e-mail: ruslan_kozoviy@ukr.net;

${ }^{5}$ Івано-Франківський національний медичний університет, кафедра патологічної анатомії,

м. Івано-Франківськ, Украӥна,

ORCID ID: 0000-0002-3894-8484,

e-mail: kindrativ2016@gmail.com

Резюме. У статті окреслені перспективи вивчення етнічних та регіональних особливостей дерматогліфічних параметрів рук і ніг, з оглядом на інтенсифікацію міграційних процесів як у межах України, так і у світових межах, щороку є причиною катастрофічного збільшення кількості людей, що проживають за межами країни чи регіону свого походження. Біженці, трудові, політичні мігранти, мігранти через расову дискримінацію та з інших причин сьогодні становлять 3\% населення світу. Зростаючий потік світової міграції, асиміляції створює всі умови для зникнення чистих етносів та народів. Сучасні науковці зацікавлені у наявності антропометричних, антропоскопічних, дерматогліфічних даних різних популяцій задля створення регіональних генофондів. Також у статті визначені переваги використання дерматогліфічного методу, що включають у себе легкість у застосуванні, фінансову необтяжливість та можливість отримання результатів у короткий термін. Проведено грунтовний аналіз літератури 3 даного питання, вивчені основні напрямки застосування дерматогліфіки. У розрізі вище висвітленої проблематики актуальним залишається питання, пов'язане з вивченням антропоскопічних, антропометричних, дерматогліфічних параметрів населення України із урахуванням регіональної, етнотериторіальної належності. Варто відмітити, що вивчення етнологічних, регіональних особливостей дерматогліфічних параметрів рук та ніг є актуальним серед світової наукової спільноти. Проте, наразі існує надто мала кількість робіт вітчизняних авторів, при- свячених вивченню регіональних, етно-територіальних особливостей дерматогліфічних параметрів, хоча 3 огляду на інтенсифікацію міграційних процесів окреслюються перспективи до ії вивчення.

Ключові слова: дерматогліфіка, етнодерматогліфіка, дерматогліфічні параметри.

\section{УДК $340.6+343$ \\ ИЗУЧЕНИЯ ЭТНИЧЕСКИХ И РЕГИОНАЛЬ- НЫХ ОСОБЕННОСТЕЙ ДЕРМАТОГЛИФИЧЕ- СКИХ ПАРАМЕТРОВ РУК И НОГ (ОБЗОР ЛИТЕРАТУРЫ)}

\author{
И.В. Гунас ${ }^{1}$, А.В. Дунаев ${ }^{2}$, О.Г. Попадинець ${ }^{3}$, \\ Р.В. Козовой ${ }^{4}$, Е.О. Киндратив ${ }^{5}$
}

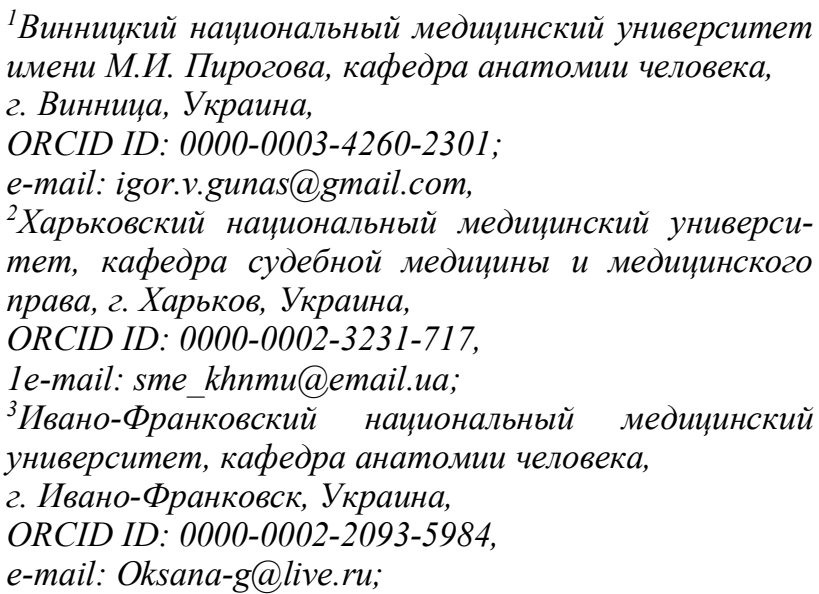
${ }^{4}$ Ивано-Франковский национальный медицинский университет, кафедра медицинской биологии и генетики, г. Ивано-Франковск, Украина,

e-mail: ruslan_kozoviy@ukr.net;

${ }^{5}$ Ивано-Франковский нацииональный медицинский университет, кафедра патологической анатомии,

2. Ивано-Франковск, Украина,

ORCID ID: 0000-0002-3894-8484,

e-mail:kindrativ2016@gmail.com

Резюме. В статье обозначены перспективы изучения этнических и региональных особенностей дерматоглифических параметров рук и ног, с оглядкой на интенсификацию миграционных процессов как в пределах Украины, так и в мирових пределах, ежегодно является причиной катастрофического увеличения количества людей, проживающих за пределами страны или региона свого происхождения. Беженцы, трудовые и политические мигранты, мигранты из-за расовой дискриминации и по другим причинам сегодня составляют 3\% населения мира. Растущий поток мировой миграции, ассимиляции создает все условия для исчезновения чистых этносов и народов. Современные ученые заинтересованы в наличии антропометрических, антропоскопических, дерматоглифических данных различных популяций для создания региональных генофондов. Определены преимущества использования дерматоглифического метода, включающие в себя легкость в применении, финансовую необременительность и возможность 
получения результатов в короткие сроки. Проведен подробный анализ литературных данных, изучены основне направления применения дерматоглифики. В разрезе выше освещенной проблематики актуальным остается вопрос, связан с изучением антропоскопических, антропометрических, дерматоглифических параметров населения Украины с учетом региональной и этнотерриториального принадлежности. Изучение этнических особенностей дерматоглифических параметров рук и ног актуальное среди мирового научного сообщества. Однако, пока существует слишком малое количество работ отечественных авторов, посвященных изучению этнотерриториальных особенностей дерматоглифических параметров, хотя учитывая интинсификацию миграционных процессов, определяются перспективы к ее изучению.

Ключевые слова: ерматоглифика, етнодерматоглифика, дерматоглифически епараметры.

Стаття надійшла в редакцію 31.08.2020 p. 